\title{
DEPOSIÇÃO DE INCONEL 625 NO AÇO AISI 4130 UTILIZANDO PROCESSO ELETRODO REVESTIDO(SMAW)
}

III Congresso Online de Engenharia de Materiais. inscrições encerradas, 3ạ edição, de 28/07/2021 a 31/07/2021 ISBN dos Anais: 000000000000000

ALVES; Élida Mariana Almeida ${ }^{1}$, SOUZA; José Vitor C. ${ }^{2}$, HEIN; Luis Rogério Oliveira ${ }^{3}$, FERRANDINI; Peterson Luiz 4

\section{RESUMO}

As propriedades de superfície de um componente de engenharia são determinantes para seu desempenho. Assim, há uma série de indústrias que costumam revestir componentes para aumentar a vida útil e, muitas vezes, o inconel é utilizado como material de revestimento. O revestimento envolve processo de soldagem com revestimento SMAW são vários os parâmentros de soldagem que influência na taxa de extração de calor e também a entrada de calor(heat puit). O Inconel 625 foi depositado sobre um substrato de aço AISI 4130, utilizando o SMAW e eletrodos revestidos de fluxo disponíveis comercialmente. Os três cordões revestidos foram produzidos usando $110 \mathrm{~A}, 140 \mathrm{~A}$ e $170 \mathrm{~A}$. Foi observado a penetração e diluição que apresentou um aumento da corrente de soldagem de 110A para 140A leva a um aumento do volume depositado e diluição aumentada de $31,8 \%$ para $44 \%$. Como respectivamente, a penetração maior foi 140A. Quando se considera um rápido aumento na velocidade de soldagem, verifica-se que a entrada de calor (heat input) mais elevada foi completamente convertida num volume depositado mais elevado. Observando que a entrada de calor (heat input) apresentou em sua geometria do revestimento, mais do que a velocidade de soldagem. Quando a velocidade de soldagem foi aumentada de 140A para 170A, por outro lado, o volume depositado não aumentou acentuadamente. De fato, a largura do revestimento e o reforço são os mesmos tanto para $140 \mathrm{~A}$ para 170A. Enquanto a dureza diminui de $(201 \pm 5) \mathrm{HV}$ a $(183 \pm 6) \mathrm{HV}$. Ao elevar a corrente de soldagem para $170 \mathrm{~A}$, tanto a diluição quanto a dureza apresentaram variação menos pronunciada, $52 \%$ e $(176 \pm 3)$ $\mathrm{HV}$, respectivamente, nota-se quanto o maior for a corrente de soldagem, menor a dureza do cordão, o que é explicado pela maior entrada de calor (heat input) uma menor taxa de resfriamento. Apesar tanto a dureza e quanto o espaçamento interdendrítico mostraram o efeito da variação de entrada de calor (heat input) é nítido que o efeito é mais forte na dureza. A variação do espaçamento inter-dendrítico foi ainda menos pronunciada. Assim sendo, o objetivo deste trabalho é relatar um estudo de deposição de inconel 625 em um substrato AISI 4130 utilizando três diferentes correntes de soldagem 110A,140A e 170A.0 inconel 625 foi depositado em aço AISI 4130, utilizando SMAW e três diferentes valores de corrente de soldagem. Os revestimentos foram analisados e conclui-se que: Aumentar a entrada de calor(heat input) não aumenta o volume depositado e a largura proporcionalmente; apesar da variação de entrada 
de calor(heat input) ,os revestimentos apresentam principalmente estrutura dendrítica, fortemente orientada ,de acordo com a direção de extração de calor; o espaçamento interdendrítico tende a aumentar com maior entrada de calor(heat input), mas o efeito não é observado; o efeito da entrada de calor (heat input) foi de uma alta dureza ; utilizando $110 \mathrm{~A}$ resultou no menor valor de penetração, o mais adequado quando se refere ao revestimento.

PALAVRAS-CHAVE: AISI 4130, Inconel, SMAW, Revestimento 